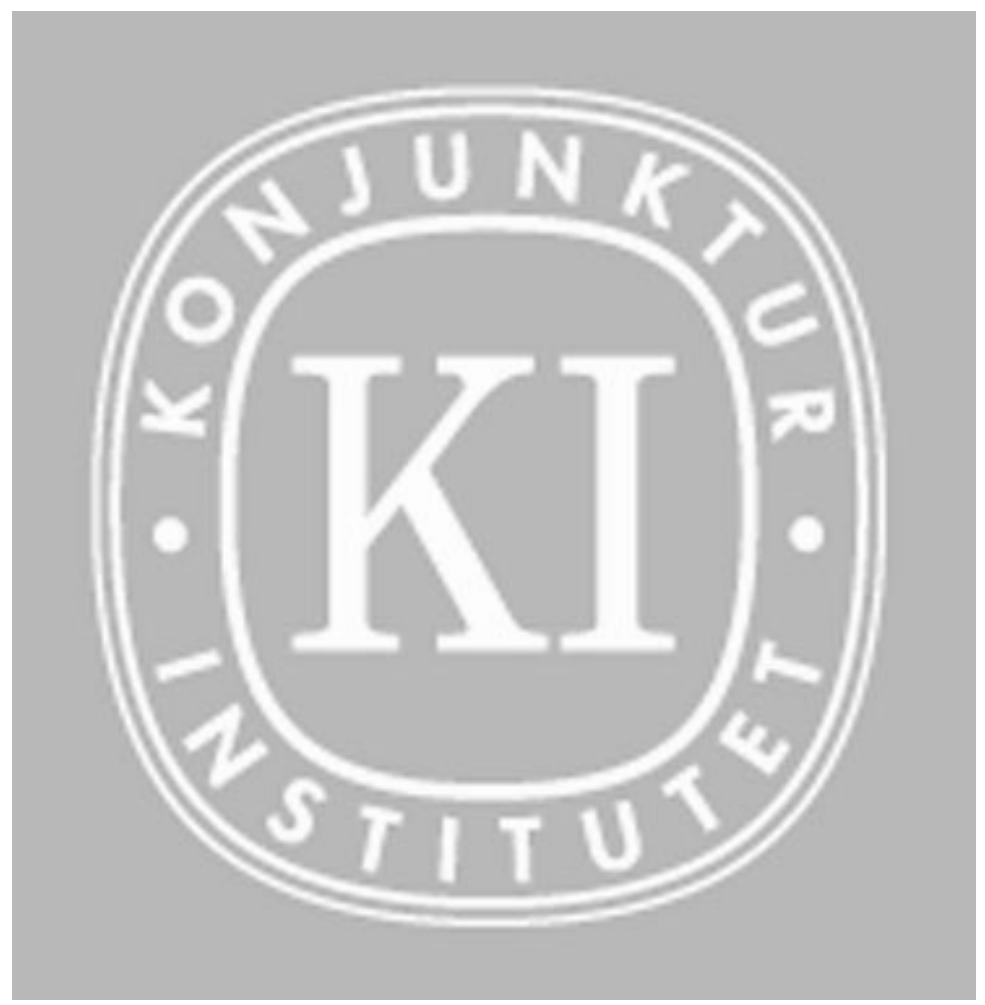

\title{
Forecasting Inflation Using Constant Gain Least Squares*
}

\author{
Jan-Erik Antipin ${ }^{\#}$
}

Farid Jimmy Boumediene ${ }^{\forall}$

Pär Österholm*

\footnotetext{
* We are grateful to seminar participants at the National Institute of Economic Research for valuable comments.

\# National Institute of Economic Research, Box 3116, 10362 Stockholm, Sweden e-mail: jan-erik.antipin@konj.se Phone: +46 84535993

${ }^{\forall}$ Ministry of Finance, Drottninggatan 21, 10333 Stockholm, Sweden email: jimmy.boumediene@finance.ministry.se Phone: +46 84052148

* Sveriges Riksbank, 10337 Stockholm, Sweden

e-mail: par.osterholm@riksbank.se Phone: +46 87870162

WORKING PAPER N0 126, FEBRUARY 2012 
NI ER prepares analyses and forecasts of the Swedish and international economy and conducts related research. NIER is a government agency accountable to the Ministry of Finance and is financed largely by Swedish government funds. Like other government agencies, NI ER has an independent status and is responsible for the assessments that it publishes.

The Working Paper series consists of publications of research reports and other detailed analyses. The reports may concern macroeconomic issues related to the forecasts of the institute, research in environmental economics, or problems of economic and statistical methods. Some of these reports are published in their final form in this series, whereas others are previews of articles that are subsequently published in international scholarly journals under the heading of Reprints. Reports in both of these series can be ordered free of charge. Most publications can also be downloaded directly from the NIER home page. 


\begin{abstract}
This paper assesses the usefulness of constant gain least squares when forecasting inflation. An out-of-sample forecast exercise is conducted, in which univariate autoregressive models for inflation in Australia, Sweden, the United Kingdom and the United States are used. The results suggest that it is possible to improve the forecast accuracy by employing constant gain least squares instead of ordinary least squares. In particular, when using a gain of 0.05 , constant gain least squares generally outperforms the corresponding autoregressive model estimated with ordinary least squares. In fact, at longer forecast horizons, the root mean square forecast error is reliably lowered for all four countries and for all lag lengths considered in the study.
\end{abstract}

JEL Classification E31, E37:

Keywords: Out-of-sample forecasts, Inflation 


\section{Summary in Swedish}

I denna studie jämförs prognosförmågan hos univariata autoregressiva modeller skattade med två olika metoder: ordinary least squares (OLS) och constant gain least squares (CGLS). Vi utvärderar modellprognoser för inflationen i Australien, Sverige, Storbritannien och USA. Resultaten visar att CGLS kan förbättra prognoser jämfört med OLS. När ett gain på 0,05 används är CGLS generellt bättre än OLS. Pålitliga förbättringar i prognosprecision erhålls på längre prognoshorisonter; CGLS ger på dessa ett lägre rotmedelkvadratfel än OLS för alla fyra länder och för alla lagstrukturer beaktade i denna studie. 


\section{Contents}

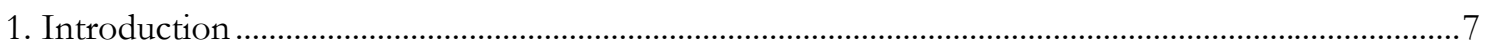

2. The modelling framework ………………………................................................................. 8

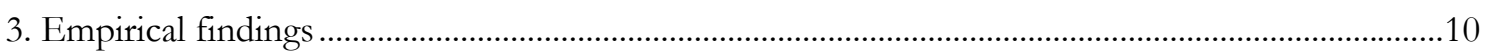

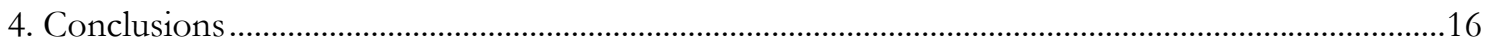

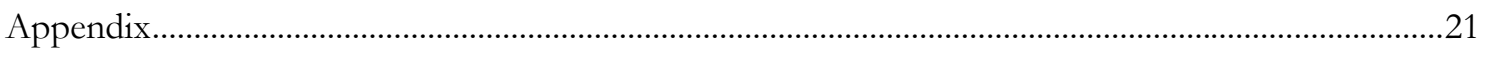





\section{Introduction}

In recent years it has been increasingly common in theoretical macroeconomics to abandon the standard assumption of rational expectations for that of adaptive learning. ${ }^{1}$ In this literature, it is generally assumed that agents know the general structure of the economy, but not the specific parameter values; typically, they are assumed to use least squares regression analysis on the existing data set to estimate the economy's true parameter values. One commonly used adaptive learning algorithm is recursive least squares (RLS). However, as pointed out by Sargent (1999), agents should use a constant gain version of RLS when economies are subject to structural change. Constant gain least squares (CGLS) assigns a higher weight to data observations the more recently they occurred. In this sense it is a recursive version of weighted least squares rather than ordinary least squares (OLS). Since economists often have reason to suspect that structural shifts have taken place, CGLS has theoretical appeal and it has accordingly become a popular tool in a range of models. ${ }^{2}$

But while being a reasonably frequently employed tool in theoretical frameworks, the empirical literature relying on CGLS as a forecasting tool is highly limited. ${ }^{3}$ This is somewhat surprising given that there are many time series - in which there is widespread interest in forecasting - that may have been subject to structural change. One of the most obvious examples is inflation. ${ }^{4}$ The introduction of explicit inflation targeting in many countries has not only brought about an increased focus on inflation forecasts - see, for example, Svensson (1997) - but it is also highly likely to have changed the time-series properties of inflation in these countries. In addition, there is a fairly large literature suggesting that US inflation has undergone changes in both mean and persistence. ${ }^{5}$ Inflation hence seems like a reasonable variable to study if one wants to investigate the empirical relevance of CGLS as a forecasting tool.

In this paper, we compare the forecast performance of simple autoregressive (AR) models for inflation estimated with CGLS with that of AR models estimated with OLS. AR models provide a reasonable starting point when it comes to comparing these two different methodological approaches since they are commonly used in empirical work and generally forecast well. As pointed out by

\footnotetext{
1 See, for example, Evans and Honkapohja (1999), Sargent (1999), Bullard and Mitra (2002) and Orphanides and Williams (2005a).

2 See, for example, Orphanides and Williams (2005b), Gaspar et al. (2006), Milani (2007), Beechey et al. (2011) and Dale et al. (2011).

3 The paper by Branch and Evans (2006) provides one example though.

4 The general literature on inflation forecasting is copious; see Stock and Watson (1999, 2007), Granger and Jeon (2003), Hubrich (2005), Marcellino (2008), Flavin et al. (2009), Wright (2009) and Beechey and Österholm (2010) for a few recent examples and Faust and Wright (2012) for further references.

5 See, for example, Cogley and Sargent (2001), Kozicki and Tinsley (2005), Cecchetti and DeBelle (2006), Stock and Watson (2007), Cogley and Sbordone (2008), Zhang and Clovis (2009) and Beechey and Österholm (2012).
} 
Stock and Watson (2007, p. 6), "it has been quite difficult for inflation forecasts to improve on simple univariate models". We focus on four countries: Australia, Sweden, the United Kingdom and the United States. The former three of these four countries have undergone explicit structural changes to monetary policy, which suggests that CGLS could have benefits as a modelling tool. The most important of these changes is of course the adoption of inflation targeting. The fixed exchange rate regime of the United Kingdom was abandoned in favour of an explicit inflation target in 1992. Australia and Sweden became explicit inflation targeters in 1993.6 Results from our simulated out-of-sample forecast exercise indicate that CGLS shows some promise as a forecasting tool. The forecast performance of CGLS typically is better than that of OLS in all four countries studied. At longer forecast horizons, substantial gains in forecast precision are made in some cases.

The rest of this paper is organised as follows: Section 2 discusses the models and estimation methods. In Section 3, the data are presented and the results are discussed. Finally, Section 4 concludes.

\section{The modelling framework}

In order to assess the empirical usefulness of CGLS as a forecasting tool, we conduct an out-ofsample forecast exercise. AR models are used for this purpose and they are estimated using the two competing methods, CGLS and OLS. These two methods have quite different status in the literature. OLS is by far the most commonly used method in empirical work - and has been so for a very long time - whereas CGLS has gained popularity more recently and is mainly used in the theoretical literature.

OLS and CGLS can also be seen as having fundamentally different assumptions regarding the underlying structure of the economy. First, CGLS assumes that the economy's true parameter values are time varying and attaches a higher weight on more recent observations. OLS, on the other hand, attaches the same weight to all observations. CGLS is hence better suited to model economies that are subject to structural change.

Consider the $\operatorname{AR}(p)$ model in equation (1):

$$
\pi_{t}=\alpha+\beta_{1} \pi_{t-1}+\beta_{2} \pi_{t-2}+\ldots+\beta_{p} \pi_{t-p}+\varepsilon_{t}
$$

\footnotetext{
6 It can be noted though that an increasing focus on achieving and maintaining low inflation had been a feature of the Reserve Bank of Australia's rhetoric since about 1989; see, for example, Grenville (1997) and Macfarlane (1998) for a historical treatment of this period.
} 
where $\pi_{t}$ is the inflation rate and $\varepsilon_{t}$ is an i.i.d. error term. If one believes that the structure of the economy does not change over time, it is a natural choice to employ OLS when estimating equation (1), since it assumes that parameters are constant within the sample. When CGLS is employed, on the other hand, time variation of the parameters is explicitly assumed. That is, we write the $\operatorname{AR}(p)$ model as

$$
\pi_{t}=\alpha_{t}+\beta_{1, t} \pi_{t-1}+\beta_{2, t} \pi_{t-2}+\ldots+\beta_{p, t} \pi_{t-p}+\varepsilon_{t}
$$

In cases where it is reasonable to assume that the economy is evolving over time in such a way that the univariate time-series properties are affected in a quantitatively meaningful way, CGLS hence has certain appeal over OLS.

To describe the time variation of the parameters associated with CGLS estimation in slightly more detail, we define the true parameter vector as: $c_{t}=\left(\begin{array}{lllll}\alpha_{t} & \beta_{1, t} & \beta_{2, t} & \ldots & \beta_{p, t}\end{array}\right)^{\prime}$. CGLS then implies that the estimated parameter vector is updated according to

$$
\hat{c}_{t}=\hat{c}_{t-1}+\kappa R_{t}^{-1} X_{t}\left(\pi_{t}-X_{t}^{\prime} \hat{c}_{t-1}\right)
$$

where

$$
R_{t}=R_{t-1}+\kappa\left(X_{t} X_{t}^{\prime}-R_{t-1}\right)
$$

and where the constant gain is denoted by $\kappa \in[0,1]$ and $X_{t}=\left(\begin{array}{lllll}1 & \pi_{t-1} & \pi_{t-2} & \ldots & \pi_{t-p}\end{array}\right)^{\prime}$. The second term on the right hand side of (3) implies that the parameter vector estimated in the previous period is updated according to the forecast error it produces for the current period. In general, the larger $\kappa$ is, the higher is the relative weight put on more recent observations and the faster are the parameter estimates to adjust to structural shifts.

In the out-of-sample forecast exercise in this paper, five different gains are used for the CGLS algo-

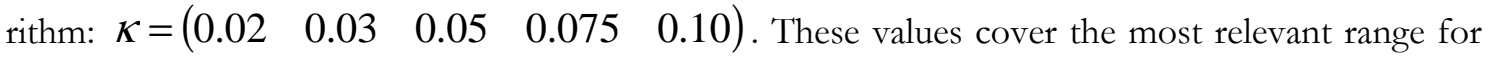
the gain used in both the theoretical and empirical literature. ${ }^{7}$ The initial value of the parameter vector is set to $C=\left(\begin{array}{lllll}0 & 1 & 0 & \ldots & 0\end{array}\right)^{\prime}$, which is consistent with a univariate random walk with-

\footnotetext{
${ }^{7}$ As a comparison, Branch and Evans (2006) found a gain of 0.0345 successful.
} 
out a drift. 8 The initial value for $R$ is set to $R=b b^{\prime}+M$, where $b$ is the $(p+1) \times 1$ vector $b=\left(\begin{array}{lllll}1 & \pi_{t-2} & \pi_{t-3} & \ldots & \pi_{t-p-1}\end{array}\right)^{\prime}$ and $M$ is the $(p+1) \times(p+1)$ diagonal matrix $M=\operatorname{diag}\left(\begin{array}{llll}0 & 0.01 & \ldots & 0.01\end{array}\right)$, which is added to $b b^{\prime}$ so that the starting value of $R$ will not be singular. ${ }^{9}$

Having briefly presented the simple modelling framework that we rely upon, we next turn to the issue of out-of-sample forecast performance. While one can hypothesize regarding time-variation in the univariate time series representation of inflation, our main objective here is to assess the merit of such an assumption on the forecast performance of simple univariate AR models.

\section{Empirical findings}

We use quarterly data on inflation in Australia, Sweden, the United Kingdom and the United States from 1970Q1 to 2009Q4, where inflation is measured as the quarter-on-quarter change in the CPI. The data are plotted in Figure 1. Although we cannot dismiss the presence of a unique equilibrium level in each country over the sample period based solely on a visual inspection, it does not seem unlikely that the unconditional mean has changed over time. Figure 1 shows that inflation was generally higher before the introduction of the inflation targeting regimes in Australia, Sweden and the United Kingdom. In the United States, there seems to have been a drop in average inflation in the early 1980s. This is commonly attributed to changes in Federal Reserve policies - including a lower implicit inflation target and/or a weaker relative preference for output stability - around the time when Volcker became chairman. ${ }^{10}$

\subsection{Benchmark models}

The out-of-sample forecast exercise is conducted as follows: The parameter values estimated by CGLS are updated according to equations (3) and (4) each quarter and forecasts from one to eight quarters ahead are generated at each point in time. ${ }^{11}$ The first forecast is generated in 1985Q1 and the last in $2007 \mathrm{Q} 4$. The same number of forecasts, 92 to be specific, is hence evaluated for all horizons. The AR model in equation (1) is estimated with OLS on an expanding sample (using the full

\footnotetext{
8 These values for the coefficients on the lags are also commonly used as priors in Bayesian analysis of AR and VAR models; see, for example, Litterman (1986) and Beechey and Österholm (2010).

${ }^{9}$ All our samples range from 1970Q1 to 2009 Q 4 (see Section 3) and the CGLS estimation is initialised in 1971Q2 to allow for a sufficient number of lags. Since the first forecast is generated in 1985Q1, this gives at least 56 periods of updating $\hat{C}_{t}$. This should be sufficient to eliminate any adverse effects caused by an inappropriately chosen initial condition, particularly since we do not use any particularly low values for the gain.

10 See, for example, Kozicki and Tinsley (2005) or Beechey and Österholm (2012).

${ }^{11}$ Forecast horizons up to eight quarters are evaluated since these are the horizons that typically receive most attention by, for example, the Bank of England (2011) and the Reserve Bank of Australia (2011).
} 
available history at each point in time), that is, the model is re-estimated each quarter. ${ }^{12}$ Forecasts from this model are also generated up to eight quarters ahead every quarter from 1985Q1 to 2007Q4. Forecast errors are recorded and used to calculate the RMSFEs, which can then be compared to identify the model that produces the most accurate forecasts.

Figure 1. CPI inflation.

Australia
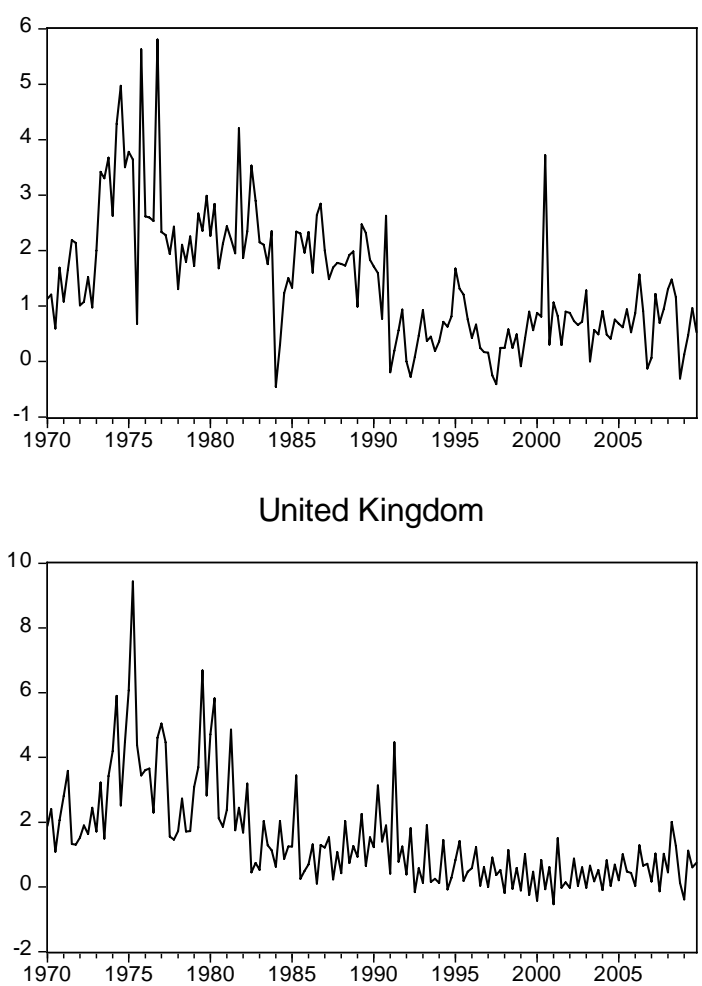

Sweden
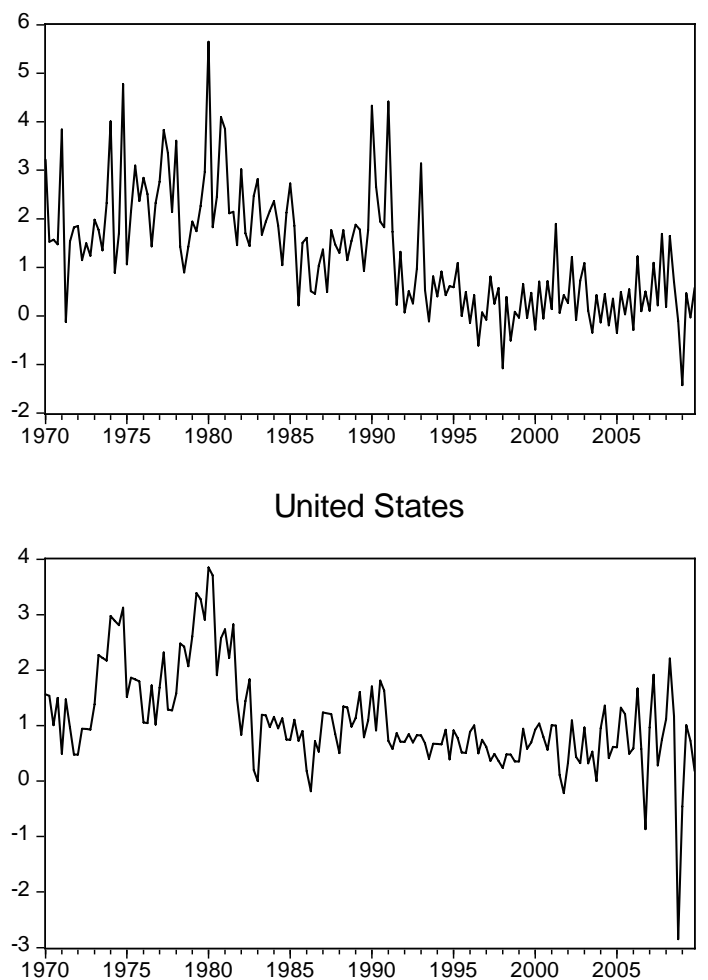

The choice of lag length in an AR model is an issue of relevance to forecasters. However, establishing the "correct" lag length is not trivial. Several methodological approaches have been suggested such as the use of different information criteria or "general-to-specific" modelling - and opinions concerning the appropriateness of different choices are diverse. ${ }^{13}$ In this paper, we circumvent this issue to a large extent through a pragmatic approach: we investigate forecast performance with respect to four different lag lengths, $p=\left(\begin{array}{llll}1 & 2 & 3 & 4\end{array}\right)$, and focus on comparisons between OLS and CGLS for a given lag length. A benefit of this approach is that it also serves as a sensitivity analysis. It is of course interesting to know whether the potential benefits of a certain approach are sensitive to the choice of lag length.

\footnotetext{
12 It can be noted that the model in equation (1) hence has constant parameters within each sample. As the model is reestimated each quarter - when a new observation is added to the sample - the parameters are updated in accordance with the RLS alogrithm; see Cogley (1993) for an analytical expression. This time variation is reasonable, seeing that the approach used in this paper mimics how the model would be used in real time when generating out-of-sample forecasts.

13 See, for example, Akaike (1974), Schwarz (1978), Hendry (1995) and Lütkepohl (2007) for examples and discussions.
} 
As a reference point, we still provide optimal lag length based on the Schwarz (1978) information criterion when applied to equation (1) estimated with OLS. This is done for two different samples, i) the initial sample used to estimate the models before the first forecast is generated, that is, 1970Q1 to 1984Q4, and ii) the full sample 1970Q1 to 2009Q4. The shorter sample is the more appropriate for our purposes, since this is the one that would initially be used in practice. It is nevertheless interesting to see whether the lag length established based on the shorter sample appears stable. Table 1 shows the results, which indicate that the optimal lag length is higher when looking at the entire sample than it is for the sub-sample 1970Q1-1984Q4. Hence, comparing different models for a given lag length seems to be a reasonable approach. ${ }^{14}$

Table 1. Optimal lag length for AR model estimated with OLS.

$\begin{array}{lcc} & \text { 1970Q1-1984Q4 } & \text { 1970Q1-2009Q4 } \\ \text { Australia } & 2 & 4 \\ \text { Sweden } & 1 & 4 \\ \text { United Kingdom } & 1 & 4 \\ \text { United States } & 1 & 3\end{array}$

Note: Lag length established using the Schwarz (1978) information criterion.

Concerning the evaluation of forecasts, we focus solely on the RMSFE and conclude that the best estimation method is the one with the lowest RMSFE. There will be no test for whether differences in forecast performance are statistically significant. In line with Armstrong (2007) and Beechey and Österholm (2010), we argue that significance testing is not particularly interesting in our setting. We compare how two reasonable alternatives perform and the best of these methods is that whose forecasts minimise the loss function of the forecaster. Few forecasters would choose a model or a method with a larger RMSFE just because it is not significantly larger.

The results from this out-of-sample forecast exercise are presented in Tables A1 to A4 in the appendix. Turning first to the results for Australia in Table A1, it can be seen that regardless of the lag length, CGLS with a gain of 0.05 produces low RMSFEs. The largest improvements in forecast accuracy from using CGLS instead of OLS are typically found for the forecasts at the longest horizons. Looking at the results for the models with the lag length as determined by the Schwarz information criterion for the sample period 1970Q1-1984Q4 (that is, AR(2), see Table 1), the reduction in the RMSFE from choosing CGLS with a gain of 0.05 instead of OLS ranges from four to 27 percent. However, with a gain of 0.1 , CGLS produces less accurate forecasts than OLS does for models with more than one lag.

\footnotetext{
14 We do not investigate what the optimal lag length would be at each point in time and try to incorporate this information. While this issue might be of some interest, it would obscure more than it clarifies since it would add several dimensions to our study. The most obvious problem is to decide how the lag length should be chosen.
} 
The results for Sweden are presented in Table A2 and show that using CGLS instead of OLS improves forecast accuracy. High gains of 0.075 and 0.1 lead to the lowest RMSFEs for the models with one or two lags, while smaller gains of 0.02 or 0.03 produce the best forecasts for the models with three or four lags. Again, CGLS with a gain of 0.05 reliably outperforms OLS. In fact, for the model with one lag it reduces the RMSFE of OLS by 19 percent for forecasts one quarter ahead and by 30 percent for an eight-quarter forecast horizon.

Turning to the United Kingdom, results are presented in Table A3. The results here are similar to those for Sweden. Forecast accuracy as measured by the RMSFE is always improved by using CGLS instead of OLS. This improvement is particularly noticeable at longer forecast horizons and larger gains work better for the AR models with fewer lags, while smaller gains produce the best forecasts of the $\operatorname{AR}(3)$ and $\operatorname{AR}(4)$ models. CGLS with a gain of 0.05 has certain appeal as its good forecast performance is not particularly sensitive to the choice of lag structure.

Finally, the results for the United States in Table A4 show a smaller percentage gain from using CGLS than in the other countries. This is perhaps not too surprising. As pointed out above, the United States differs from the other economies studied here in that it has not undergone any significant explicit shifts in monetary policy during the evaluation period. While a gain of 0.05 reduces the RMSFE by between 12 and 21 percent for the AR(1) model depending on the forecast horizon, the improvements in forecast accuracy are more modest for models with more lags. For example, for the AR(4) model, the improvement at the eight-quarter horizon is only seven percent. As was the case for Sweden and the United Kingdom, CGLS works better with larger large gains for the specifications with fewer lags, while smaller gains produce better forecasts for models with more lags.

In sum, the forecast performance of simple AR models for CPI inflation can be improved by employing CGLS instead of OLS. The gain that minimizes the RMSFE of the models estimated with CGLS generally depends on the number of lags in the model. But as a rule of thumb, a gain of 0.05 produces good forecasts regardless of lag structure. The benefits from using CGLS instead of OLS increase with longer forecast horizons. We illustrate the robustness of our result in Figure 2.

Figure 2 shows the RMSFEs for $\mathrm{AR}(p)$ models estimated by CGLS relative to those obtained when using OLS. For CGLS, results with two gains are reported - a gain of 0.05 and the gain that on average results in the lowest RMSFE given the lag length. In the cases where a gain of 0.05 results in the lowest RMSFE, the gain producing the second lowest RMSFE is depicted. The lag length used for each country is that from the left column of Table 1, that is, it was selected using the Schwarz (1978) information criterion for the model estimated with OLS on the sample 1970Q1-1984Q4. We define the relative RMSFE at horizon $h$ as 
$R R_{h}=\frac{R M S F E_{C G L S, h}}{R M S F E_{O L S, h}}$,

where $R M S F E_{C G L S, h}$ is the RMSFE of the AR model estimated with CGLS at horizon $h$ and $R M S F E_{O L S, h}$ is the corresponding-horizon RMSFE for the AR model estimated with OLS. A relative RMSFE smaller than unity hence implies that CGLS is associated with higher forecast precision than OLS. As can be seen from Figure 2, CGLS improves the inflation forecasts in all cases. Furthermore, it is evident that the benefit from using CGLS increases substantially with the forecast horizon. At the eight-quarter horizon, the reduction in the RMSFEs from using CGLS ranges from 21 percent in the United States to nearly 50 percent in the United Kingdom. 
Figure 2. Relative RMSFEs for out-of-sample forecasts generated 1985Q1-2007Q4, CGLS versus OLS.
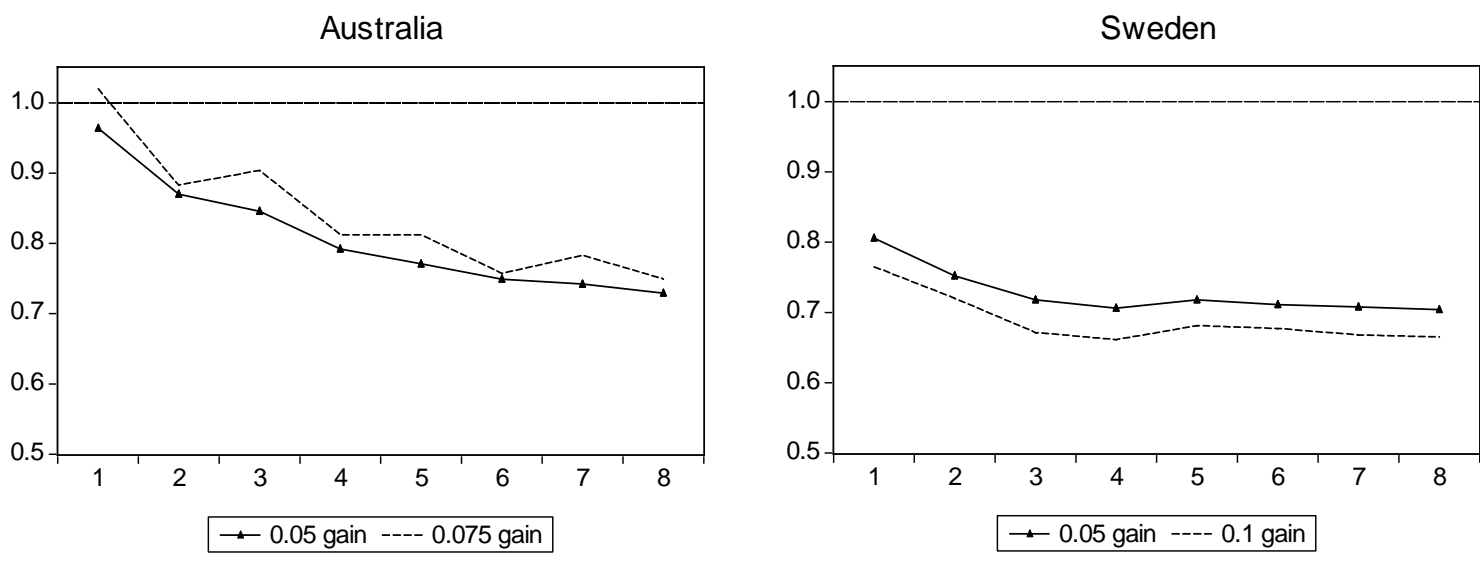

United Kingdom
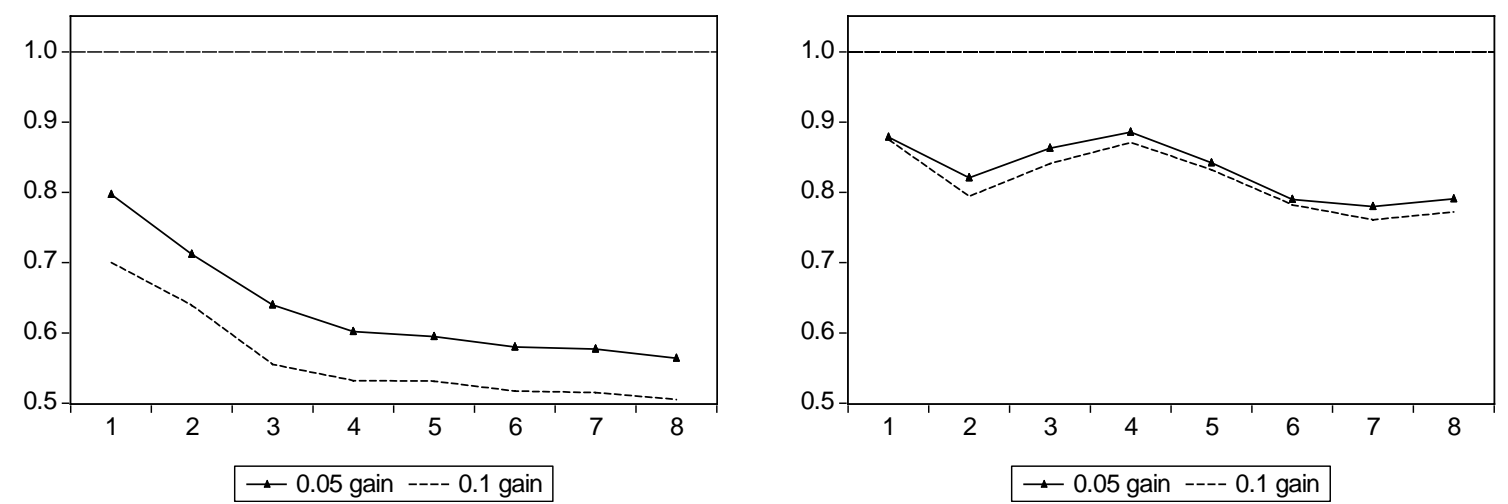

Note: Forecast horizon in quarters on the horizontal axis and relative RMSFE on the vertical. A relative RMSFE smaller than one indicates that the CGLS generates better forecasts than OLS. Lag length for the model estimated with OLS has been established using the Schwarz (1978) information criterion on the sample 1970Q1-1984Q4. Lag length in the model estimated with CGLS is chosen to be the same as that of the OLS model.

\subsection{Sensitivity analysis}

The analysis conducted so far in this paper indicates that CGLS has merits as a forecasting tool relative to OLS. In order to assess the robustness of this conclusion, we next conduct some sensitivity analysis. A potential shortcoming with the analysis conducted above is that the AR models estimated with OLS may be overly restrictive. In particular, one might be concerned that the inflation-targeting regime is associated with inflation that on average is lower than the preceding period's. Using constant parameters within the sample in such a case can of course deteriorate forecast precision. We therefore investigate whether the inclusion of a dummy variable for the likely level shift associated with the adoption of an inflation target changes our conclusions. Instead of equation (1), we hence estimate the following equation with OLS in the out-of-sample forecast exercise: 
$\pi_{t}=\alpha+\beta_{1} \pi_{t-1}+\beta_{2} \pi_{t-2}+\ldots+\beta_{p} \pi_{t-p}+\theta D_{t}+\varepsilon_{t}$,

where $D_{t}=1$ in the presence of an inflation targeting regime and 0 otherwise. Such an intercept shift is a common way to address this issue in the empirical literature. 15 The exact date that the dummy variable should start taking on the value 1 in the different countries can be a matter of discussion since there is some room for interpretation. For example, Sveriges Riksbank declared in January 1993 that it was turning to inflation targeting but that the target would not begin to apply until 1995. However, for both Australia and Sweden there are fairly good reasons to choose 1993Q1 as the start of the inflation-targeting regime. ${ }^{16}$ For the United Kingdom it seems uncontroversial to choose 1992Q4 as the corresponding date. Not only do these dates seem reasonable from a historical perspective, they are also in line with previous empirical work. ${ }^{17}$ For the sake of comparison, we also conduct this out-of-sample forecast exercise for the United States even though no shift to explicit inflation targeting has taken place there. The dating of the dummy variable is the same as for Australia and Sweden.

Evaluating the forecasts over the same sample as before, results for each country are given in the rightmost column of Tables A1 to A4 in the appendix. As can be seen, using the model with a dummy variable [that is, the model in equation (6)] - rather than that without a dummy variable [that is, the model in equation (1)] - generally lowers the RMSFEs. However, the improvements in forecast performance are not large enough to change our earlier conclusions; CGLS, for example with a gain of 0.05 , still tends to generate better forecasts than OLS.

\section{Conclusions}

Despite the increasing popularity of CGLS as a modelling tool in macroeconomics, the literature evaluating CGLS as a forecasting tool is limited. This paper has investigated the empirical performance of CGLS in an out-of-sample forecast exercise using AR models for CPI inflation in Australia, Sweden, the United Kingdom and the United States. Comparing RMSFEs, we find that it is possible to improve on the forecast performance of AR models by employing CGLS instead of OLS. In particular, using a gain of 0.05 reliably reduces the RMSFE at longer forecast horizons in all countries and for all lag lengths.

\footnotetext{
15 See, for example, Adolfson et al. (2007) and Beechey and Österholm (2010).

16 It can be noted that a speech by the Reserve Bank of Australia's governor Fraser in March 1993 is often considered the official turn to inflation targeting in Australia; see, for example, Stevens (1999).

17 See, for example, Beechey and Österholm (2010).
} 
Out-of-sample forecast performance can be seen as a way to assess the validity of different econometric models; see, for example, MacDonald and Taylor (1992) and Carruth et al. (1998). The results from the out-of-sample forecast exercise can therefore be seen as supporting the use of CGLS as a modelling tool. The fact that a gain of 0.05 consistently performs well supports the idea that changes to the determinants of the time-series properties of inflation - such as monetary policy, price rigidities and inflationary expectations - affect inflation so that its time-series properties indeed change over time. Many macroeconomic variables can be suspected of having time-series properties that are changing over time. This raises the question of whether usage of CGLS might be a reasonable recommendation in general when forecasting macroeconomic time series using AR models. It should, however, also be noted that even if many time series may have time-varying time-series properties, it is not necessarily the case that the time variation in question is well approximated by CGLS. Further research of the forecast performance of CGLS is, needless to say, required. It is nevertheless the case that CGLS appears to have the potential to successfully contribute to the toolkit employed by macroeconomic forecasters. 


\section{References}

Adolfson, M., Andersson, M. K., Lindé, J., Villani, M. and Vredin, A. (2007), "Modern Forecasting Models in Action: Improving Macroeconomic Analyses at Central Banks", International Journal of Central Banking 3, 111-144.

Akaike, H. (1974), “A New Look at the Statistical Model Identification”, IEEE Transactions on Automatic Control 19, 716-723.

Armstrong, J. S. (2007), "Significance Tests Harm Progress in Forecasting", International Journal of Forecasting 23, 321-327.

Bank of England (2011), Inflation Report, August 2011.

Beechey, M., Johannsen, B. K. and Levin, A. T. (2011), "Are Long-Run Inflation Expectations Anchored More Firmly in the Euro Area Than in the United States?", American Economic Journals: Macroeconomics 3, 104-129.

Beechey, M. and Österholm, P. (2010), "Forecasting Inflation in an Inflation Targeting Regime: A Role for Informative Steady-State Priors", International Journal of Forecasting 26, 248-264.

Beechey, M. and Österholm, P. (2012), "The Rise and Fall of U.S. Inflation Persistence", Forthcoming in International Journal of Central Banking.

Branch, W. A. and Evans, G. H. (2006), "A Simple Recursive Forecasting Model”, Economics Letters 91, 158-166.

Bullard, J. and Mitra, K. (2002), "Learning about Monetary Policy Rules", Journal of Monetary Economics 49, 1105-1129.

Cecchetti, S. G. and DeBelle, G. (2006), "Has the Inflation Process Changed?", Economic Policy 21, 311-352.

Cogley, T. (1993), “Adapting to Instability in Money Demand: Forecasting Money Growth with a Time-Varying Parameter Model”, Federal Reserve Bank of San Fransisco Economic Review 1993-3, $35-41$.

Cogley, T. and Sargent, T. J. (2001), "Evolving Post-World War II U.S. Inflation Dynamics", NBER Macroeconomics Annual 16, 331-373.

Cogley, T. and Sbordone, A. M. (2008), "Trend Inflation, Indexation, and Inflation Persistence in the New Keynesian Phillips Curve”, American Economic Review 98, 2101-2126.

Dale, S., Orphanides, A. and Österholm, P. (2011), "Imperfect Central Bank Communication: Information versus Distraction", International Journal of Central Banking 7, 3-39.

Evans, G. and Honkapohja, S. (1999), "Learning Dynamics", in Taylor, J. B. and Woodford, M., (eds), Handbook of Macroeconomics. Elsevier, Amsterdam.

Evans, G. W. and Honkapohja, S. (2001), Learning and Expectations in Macroeconomics. Princeton University Press, Princeton. 
Faust, J. and Wright, J. H. (2012), “Forecasting Inflation”, Unpublished manuscript, Johns Hopkins University.

Flavin, T., Panopoulou, E. and Pantelidis, T. (2009), "Forecasting Growth and Inflation in an Enlarged Euro Area", Journal of Forecasting 28, 405-425.

Gaspar, V., Smets, F. and Vestin, D. (2006), “Adaptive Learning, Persistence and Optimal Monetary Policy", Journal of the European Economic Association 4, 376-685.

Granger, C. W. J. and Jeon, Y. (2003), "Comparing Forecasts of Inflation Using Time Distance”, International Journal of Forecasting 19, 339-349.

Grenville, S. (1997), "The Evolution of Monetary Policy: From Money Targets to Inflation Targets," in Lowe, P. W. (ed), Monetary Policy and Inflation Targeting. Reserve Bank of Australia, Sydney.

Hendry, D. F. (1995), Dynamic Econometrics. Oxford University Press, Oxford.

Hubrich K. (2005), "Forecasting Euro Area Inflation: Does Aggregating Forecasts by HICP Component Improve Forecast Accuracy?”, International Journal of Forecasting 21, 119-136.

Kozicki, S. and Tinsley, P. A. (2005), "Permanent and Transitory Policy Shocks in an Empirical Macro Model with Asymmetric Information", Joumal of Economic Dynamics and Control 29, 1985-2015.

Litterman, R. B. (1986), "Forecasting with Bayesian Vector Autoregressions - Five Years of Experience", Journal of Business and Economic Statistics 5, 25-38.

Lütkephol, H. (2007), "General-to-Specific or Specific-to-General Modelling? An Opinion on Current Econometric Terminology", Journal of Econometrics 136, 319-324.

MacDonald, R. and Taylor, M. P. (1992), "Exchange Rate Economics: A Survey", IMF Staff Papers 39, 1-57.

Macfarlane, I. J. (1998), "Australian Monetary Policy in the Last Quarter of the Twentieth Century", Reserve Bank of Australia Bulletin, October, 6-19.

Marcellino, M. (2008), “A Benchmark for Models of Growth and Inflation”, Journal of Forecasting 27, 305-340.

Milani, F. (2007), "Expectations, Learning and Macroeconomic Persistence", Journal of Monetary Economics 54, 2065-2082.

Orphanides, A. and Williams, J. C. (2005a), "The Decline of Activist Stabilization Policy: Natural Rate Misperceptions, Learning and Expectations", Journal of Economic Dynamics and Control 29, 1927-1950.

Orphanides, A. and Williams, J. C. (2005b), "Inflation Scares and Forecast-Based Monetary Policy", Review of Economic Dynamics 8, 498- 527.

Reserve Bank of Australia (2011), Statement of Monetary Policy, August 2011.

Schwarz, G. (1978), "Estimating the Dimension of a Model", Annals of Statistics 6, 461-464.

Stevens, G. R. (1999), "Six Years of Inflation Targeting", Reserve Bank of Australia Bulletin, May 1999, 46-61. 
Stock, J. H. and Watson, M. W. (1999), "Forecasting Inflation", Journal of Monetary Economics 44, 293-335.

Stock, J. H. and Watson, M. W. (2007), "Why Has U.S. Inflation Become Harder to Forecast?", Journal of Money, Credit and Banking 39, 3-33.

Svensson, L. E. O. (1997), "Inflation Forecast Targeting: Implementing and Monitoring Inflation Targets", European Economic Review 41, 1111-1146.

Wright, J. H. (2009), "Forecasting U.S. Inflation by Bayesian Model Averaging”, Journal of Forecasting $28,131-144$.

Zhang, C. and Clovis, J. (2009), "Modeling US Inflation Dynamics: Persistence and Monetary Policy Regime", Empirical Economics 36, 455-477. 


\section{Appendix - Results from out-of-sample forecasts}

Table A1. RMSFEs at different forecast horizons for model estimated with CGLS and OLS Australia

\begin{tabular}{|c|c|c|c|c|c|c|c|c|}
\hline & Gain & 0.02 & 0.03 & 0.05 & 0.075 & 0.10 & OLS & OLS with dummy \\
\hline \multirow[t]{9}{*}{1 lag } & Horizon & & & & & & & \\
\hline & 1 & 0.721 & 0.703 & 0.687 & 0.706 & 0.754 & 0.814 & 0.781 \\
\hline & 2 & 0.793 & 0.750 & 0.703 & 0.696 & 0.742 & 0.981 & 0.930 \\
\hline & 3 & 0.863 & 0.810 & 0.751 & 0.739 & 0.817 & 1.091 & 1.027 \\
\hline & 4 & 0.917 & 0.855 & 0.788 & 0.778 & 0.892 & 1.166 & 1.080 \\
\hline & 5 & 0.952 & 0.885 & 0.809 & 0.786 & 0.909 & 1.213 & 1.114 \\
\hline & 6 & 0.977 & 0.908 & 0.830 & 0.804 & 0.952 & 1.241 & 1.132 \\
\hline & 7 & 0.987 & 0.918 & 0.839 & 0.812 & 0.995 & 1.258 & 1.152 \\
\hline & 8 & 1.001 & 0.933 & 0.852 & 0.823 & 1.037 & 1.275 & 1.169 \\
\hline \multirow[t]{9}{*}{2 lags } & Horizon & & & & & & & \\
\hline & 1 & 0.690 & 0.677 & 0.681 & 0.721 & 0.791 & 0.707 & 0.697 \\
\hline & 2 & 0.736 & 0.698 & 0.670 & 0.679 & 0.739 & 0.770 & 0.763 \\
\hline & 3 & 0.812 & 0.760 & 0.735 & 0.785 & 0.968 & 0.868 & 0.866 \\
\hline & 4 & 0.874 & 0.803 & 0.752 & 0.771 & 0.948 & 0.950 & 0.937 \\
\hline & 5 & 0.937 & 0.855 & 0.797 & 0.839 & 1.178 & 1.033 & 1.008 \\
\hline & 6 & 0.976 & 0.885 & 0.813 & 0.822 & 1.164 & 1.085 & 1.050 \\
\hline & 7 & 0.999 & 0.902 & 0.833 & 0.878 & 1.488 & 1.122 & 1.088 \\
\hline & 8 & 1.028 & 0.925 & 0.846 & 0.869 & 1.553 & 1.161 & 1.120 \\
\hline \multirow[t]{9}{*}{3 lags } & Horizon & & & & & & & \\
\hline & 1 & 0.673 & 0.665 & 0.681 & 0.735 & 0.819 & 0.673 & 0.669 \\
\hline & 2 & 0.702 & 0.676 & 0.662 & 0.693 & 0.774 & 0.709 & 0.709 \\
\hline & 3 & 0.753 & 0.717 & 0.704 & 0.771 & 0.983 & 0.769 & 0.774 \\
\hline & 4 & 0.827 & 0.775 & 0.741 & 0.779 & 1.001 & 0.853 & 0.853 \\
\hline & 5 & 0.878 & 0.814 & 0.770 & 0.822 & 1.223 & 0.916 & 0.910 \\
\hline & 6 & 0.921 & 0.851 & 0.804 & 0.833 & 1.253 & 0.969 & 0.960 \\
\hline & 7 & 0.944 & 0.866 & 0.817 & 0.876 & 1.589 & 1.004 & 0.999 \\
\hline & 8 & 0.975 & 0.889 & 0.833 & 0.867 & 1.657 & 1.043 & 1.035 \\
\hline \multirow[t]{9}{*}{4 lags } & Horizon & & & & & & & \\
\hline & 1 & 0.670 & 0.665 & 0.687 & 0.750 & 0.852 & 0.660 & 0.658 \\
\hline & 2 & 0.692 & 0.673 & 0.674 & 0.723 & 0.830 & 0.684 & 0.685 \\
\hline & 3 & 0.735 & 0.712 & 0.716 & 0.797 & 1.018 & 0.731 & 0.735 \\
\hline & 4 & 0.793 & 0.758 & 0.743 & 0.799 & 1.035 & 0.793 & 0.794 \\
\hline & 5 & 0.851 & 0.806 & 0.786 & 0.886 & 1.392 & 0.859 & 0.858 \\
\hline & 6 & 0.888 & 0.836 & 0.812 & 0.892 & 1.467 & 0.900 & 0.897 \\
\hline & 7 & 0.908 & 0.851 & 0.834 & 0.991 & 2.062 & 0.927 & 0.928 \\
\hline & 8 & 0.941 & 0.876 & 0.848 & 0.964 & 2.237 & 0.964 & 0.962 \\
\hline
\end{tabular}

Note: Forecast horizon is given in quarters. Out-of-sample forecasts are generated 1985Q1-2007Q4. 
Table A2. RMSFEs at different forecast horizons for model estimated by CGLS and OLS Sweden.

\begin{tabular}{|c|c|c|c|c|c|c|c|c|}
\hline & Gain & 0.02 & 0.03 & 0.05 & 0.075 & 0.10 & OLS & OLS with dummy \\
\hline \multirow[t]{9}{*}{1 lag } & Horizon & & & & & & & \\
\hline & 1 & 0.914 & 0.894 & 0.856 & 0.826 & 0.811 & 1.061 & 0.984 \\
\hline & 2 & 0.960 & 0.928 & 0.895 & 0.870 & 0.856 & 1.190 & 1.067 \\
\hline & 3 & 1.025 & 0.976 & 0.913 & 0.873 & 0.853 & 1.271 & 1.085 \\
\hline & 4 & 1.046 & 0.991 & 0.925 & 0.886 & 0.865 & 1.309 & 1.098 \\
\hline & 5 & 1.111 & 1.052 & 0.982 & 0.946 & 0.931 & 1.368 & 1.152 \\
\hline & 6 & 1.107 & 1.045 & 0.974 & 0.939 & 0.927 & 1.370 & 1.149 \\
\hline & 7 & 1.116 & 1.051 & 0.975 & 0.935 & 0.920 & 1.377 & 1.162 \\
\hline & 8 & 1.118 & 1.052 & 0.973 & 0.932 & 0.919 & 1.382 & 1.171 \\
\hline \multirow[t]{9}{*}{2 lags } & Horizon & & & & & & & \\
\hline & 1 & 0.856 & 0.848 & 0.834 & 0.828 & 0.834 & 0.989 & 0.982 \\
\hline & 2 & 0.916 & 0.908 & 0.895 & 0.889 & 0.894 & 1.091 & 1.068 \\
\hline & 3 & 0.970 & 0.944 & 0.903 & 0.875 & 0.861 & 1.178 & 1.084 \\
\hline & 4 & 0.994 & 0.959 & 0.911 & 0.880 & 0.867 & 1.226 & 1.096 \\
\hline & 5 & 1.076 & 1.035 & 0.976 & 0.936 & 0.918 & 1.311 & 1.152 \\
\hline & 6 & 1.067 & 1.021 & 0.963 & 0.931 & 0.923 & 1.320 & 1.149 \\
\hline & 7 & 1.089 & 1.037 & 0.970 & 0.932 & 0.918 & 1.343 & 1.162 \\
\hline & 8 & 1.090 & 1.035 & 0.968 & 0.929 & 0.912 & 1.352 & 1.171 \\
\hline \multirow[t]{9}{*}{3 lags } & Horizon & & & & & & & \\
\hline & 1 & 0.834 & 0.825 & 0.815 & 0.820 & 0.840 & 0.910 & 0.908 \\
\hline & 2 & 0.840 & 0.839 & 0.840 & 0.843 & 0.851 & 0.929 & 0.943 \\
\hline & 3 & 0.861 & 0.849 & 0.822 & 0.796 & 0.780 & 0.947 & 0.927 \\
\hline & 4 & 0.881 & 0.873 & 0.860 & 0.850 & 0.854 & 1.010 & 0.996 \\
\hline & 5 & 1.001 & 0.988 & 0.962 & 0.943 & 0.946 & 1.131 & 1.099 \\
\hline & 6 & 0.968 & 0.952 & 0.932 & 0.926 & 0.941 & 1.117 & 1.087 \\
\hline & 7 & 1.002 & 0.977 & 0.944 & 0.936 & 0.967 & 1.175 & 1.120 \\
\hline & 8 & 0.998 & 0.971 & 0.938 & 0.929 & 0.961 & 1.191 & 1.141 \\
\hline \multirow[t]{9}{*}{4 lags } & Horizon & & & & & & & \\
\hline & 1 & 0.794 & 0.793 & 0.814 & 0.851 & 0.889 & 0.837 & 0.852 \\
\hline & 2 & 0.818 & 0.824 & 0.848 & 0.879 & 0.908 & 0.858 & 0.877 \\
\hline & 3 & 0.803 & 0.795 & 0.795 & 0.805 & 0.821 & 0.843 & 0.851 \\
\hline & 4 & 0.841 & 0.840 & 0.844 & 0.857 & 0.884 & 0.894 & 0.904 \\
\hline & 5 & 0.948 & 0.939 & 0.936 & 0.964 & 1.023 & 1.026 & 1.037 \\
\hline & 6 & 0.920 & 0.915 & 0.920 & 0.954 & 1.022 & 1.009 & 1.025 \\
\hline & 7 & 0.935 & 0.924 & 0.916 & 0.946 & 1.041 & 1.037 & 1.045 \\
\hline & 8 & 0.931 & 0.923 & 0.916 & 0.949 & 1.052 & 1.054 & 1.071 \\
\hline
\end{tabular}

Note: Forecast horizon is given in quarters. Out-of-sample forecasts are generated 1985Q1-2007Q4. 
Table A3. RMSFEs at different forecast horizons for model estimated by CGLS and OLS United Kingdom.

\begin{tabular}{|c|c|c|c|c|c|c|c|c|}
\hline & Gain & 0.02 & 0.03 & 0.05 & 0.075 & 0.10 & OLS & OLS with dummy \\
\hline \multirow[t]{9}{*}{1 lag } & Horizon & & & & & & & \\
\hline & 1 & 1.019 & 0.974 & 0.886 & 0.811 & 0.778 & 1.112 & 1.044 \\
\hline & 2 & 0.963 & 0.903 & 0.827 & 0.768 & 0.742 & 1.161 & 1.046 \\
\hline & 3 & 1.086 & 0.989 & 0.866 & 0.793 & 0.752 & 1.354 & 1.184 \\
\hline & 4 & 1.070 & 0.961 & 0.834 & 0.769 & 0.737 & 1.387 & 1.184 \\
\hline & 5 & 1.138 & 1.017 & 0.882 & 0.815 & 0.788 & 1.482 & 1.252 \\
\hline & 6 & 1.137 & 1.010 & 0.870 & 0.802 & 0.775 & 1.500 & 1.270 \\
\hline & 7 & 1.144 & 1.014 & 0.874 & 0.806 & 0.780 & 1.515 & 1.269 \\
\hline & 8 & 1.139 & 1.004 & 0.858 & 0.791 & 0.768 & 1.521 & 1.278 \\
\hline \multirow[t]{9}{*}{2 lags } & Horizon & & & & & & & \\
\hline & 1 & 0.866 & 0.829 & 0.793 & 0.780 & 0.783 & 0.927 & 0.903 \\
\hline & 2 & 0.843 & 0.794 & 0.749 & 0.733 & 0.738 & 0.937 & 0.905 \\
\hline & 3 & 0.944 & 0.851 & 0.755 & 0.706 & 0.691 & 1.090 & 1.029 \\
\hline & 4 & 0.923 & 0.814 & 0.718 & 0.680 & 0.681 & 1.102 & 1.018 \\
\hline & 5 & 1.075 & 0.959 & 0.853 & 0.797 & 0.774 & 1.266 & 1.153 \\
\hline & 6 & 1.078 & 0.946 & 0.830 & 0.785 & 0.798 & 1.295 & 1.176 \\
\hline & 7 & 1.115 & 0.968 & 0.837 & 0.773 & 0.747 & 1.348 & 1.200 \\
\hline & 8 & 1.115 & 0.955 & 0.817 & 0.761 & 0.757 & 1.365 & 1.212 \\
\hline \multirow[t]{9}{*}{3 lags } & Horizon & & & & & & & \\
\hline & 1 & 0.867 & 0.834 & 0.806 & 0.797 & 0.800 & 0.927 & 0.904 \\
\hline & 2 & 0.823 & 0.784 & 0.749 & 0.737 & 0.741 & 0.915 & 0.889 \\
\hline & 3 & 0.915 & 0.838 & 0.752 & 0.707 & 0.696 & 1.057 & 1.008 \\
\hline & 4 & 0.874 & 0.787 & 0.705 & 0.670 & 0.672 & 1.055 & 0.988 \\
\hline & 5 & 1.034 & 0.941 & 0.848 & 0.795 & 0.782 & 1.226 & 1.131 \\
\hline & 6 & 1.024 & 0.918 & 0.820 & 0.778 & 0.804 & 1.248 & 1.150 \\
\hline & 7 & 1.067 & 0.945 & 0.830 & 0.767 & 0.753 & 1.307 & 1.180 \\
\hline & 8 & 1.059 & 0.924 & 0.804 & 0.748 & 0.757 & 1.321 & 1.190 \\
\hline \multirow[t]{9}{*}{4 lags } & Horizon & & & & & & & \\
\hline & 1 & 0.638 & 0.617 & 0.604 & 0.623 & 0.660 & 0.672 & 0.668 \\
\hline & 2 & 0.616 & 0.590 & 0.575 & 0.592 & 0.628 & 0.660 & 0.659 \\
\hline & 3 & 0.634 & 0.603 & 0.585 & 0.596 & 0.621 & 0.685 & 0.685 \\
\hline & 4 & 0.615 & 0.580 & 0.557 & 0.563 & 0.583 & 0.670 & 0.668 \\
\hline & 5 & 0.780 & 0.734 & 0.707 & 0.739 & 0.819 & 0.847 & 0.838 \\
\hline & 6 & 0.766 & 0.711 & 0.679 & 0.720 & 0.820 & 0.850 & 0.844 \\
\hline & 7 & 0.796 & 0.732 & 0.694 & 0.726 & 0.804 & 0.896 & 0.884 \\
\hline & 8 & 0.780 & 0.711 & 0.666 & 0.694 & 0.760 & 0.887 & 0.879 \\
\hline
\end{tabular}

Note: Forecast horizon is given in quarters. Out-of-sample forecasts are generated 1985Q1-2007Q4. 
Table A4. RMSFEs at different forecast horizons for model estimated by CGLS and OLS United States.

\begin{tabular}{|c|c|c|c|c|c|c|c|c|}
\hline & Gain & 0.02 & 0.03 & 0.05 & 0.075 & 0.10 & OLS & OLS with dummy \\
\hline \multirow[t]{9}{*}{1 lag } & Horizon & & & & & & & \\
\hline & & 0.495 & 0.476 & 0.452 & 0.447 & 0.450 & 0.514 & 0.502 \\
\hline & & 0.577 & 0.545 & 0.506 & 0.492 & 0.489 & 0.616 & 0.596 \\
\hline & & 0.521 & 0.504 & 0.487 & 0.477 & 0.474 & 0.564 & 0.550 \\
\hline & & 0.664 & 0.646 & 0.629 & 0.621 & 0.618 & 0.710 & 0.680 \\
\hline & & 0.699 & 0.668 & 0.641 & 0.632 & 0.633 & 0.761 & 0.719 \\
\hline & & 0.704 & 0.661 & 0.624 & 0.615 & 0.618 & 0.791 & 0.736 \\
\hline & & 0.693 & 0.650 & 0.610 & 0.596 & 0.595 & 0.782 & 0.728 \\
\hline & & 0.690 & 0.651 & 0.613 & 0.600 & 0.599 & 0.775 & 0.725 \\
\hline \multirow[t]{9}{*}{2 lags } & Horizon & & & & & & & \\
\hline & 1 & 0.502 & 0.480 & 0.437 & 0.422 & 0.422 & 0.512 & 0.502 \\
\hline & 2 & 0.570 & 0.535 & 0.485 & 0.467 & 0.467 & 0.592 & 0.581 \\
\hline & 3 & 0.512 & 0.496 & 0.482 & 0.476 & 0.484 & 0.525 & 0.522 \\
\hline & 4 & 0.658 & 0.640 & 0.622 & 0.621 & 0.628 & 0.671 & 0.654 \\
\hline & 5 & 0.697 & 0.662 & 0.617 & 0.589 & 0.581 & 0.729 & 0.698 \\
\hline & 6 & 0.699 & 0.654 & 0.604 & 0.573 & 0.570 & 0.759 & 0.717 \\
\hline & 7 & 0.686 & 0.642 & 0.599 & 0.566 & 0.545 & 0.733 & 0.698 \\
\hline & 8 & 0.687 & 0.646 & 0.617 & 0.587 & 0.569 & 0.721 & 0.691 \\
\hline \multirow[t]{9}{*}{3 lags } & Horizon & & & & & & & \\
\hline & 1 & 0.421 & 0.421 & 0.418 & 0.422 & 0.431 & 0.430 & 0.429 \\
\hline & 2 & 0.474 & 0.471 & 0.467 & 0.470 & 0.479 & 0.491 & 0.492 \\
\hline & 3 & 0.468 & 0.469 & 0.476 & 0.486 & 0.499 & 0.476 & 0.481 \\
\hline & 4 & 0.647 & 0.648 & 0.645 & 0.649 & 0.658 & 0.647 & 0.642 \\
\hline & 5 & 0.664 & 0.654 & 0.628 & 0.616 & 0.623 & 0.682 & 0.674 \\
\hline & 6 & 0.655 & 0.646 & 0.629 & 0.626 & 0.641 & 0.684 & 0.676 \\
\hline & 7 & 0.634 & 0.641 & 0.643 & 0.635 & 0.639 & 0.647 & 0.643 \\
\hline & 8 & 0.622 & 0.631 & 0.642 & 0.647 & 0.662 & 0.635 & 0.633 \\
\hline \multirow[t]{9}{*}{4 lags } & Horizon & & & & & & & \\
\hline & 1 & 0.424 & 0.425 & 0.429 & 0.438 & 0.450 & 0.436 & 0.435 \\
\hline & 2 & 0.472 & 0.468 & 0.473 & 0.488 & 0.506 & 0.502 & 0.505 \\
\hline & 3 & 0.466 & 0.465 & 0.473 & 0.488 & 0.505 & 0.489 & 0.493 \\
\hline & 4 & 0.645 & 0.644 & 0.645 & 0.659 & 0.680 & 0.661 & 0.656 \\
\hline & 5 & 0.643 & 0.620 & 0.594 & 0.594 & 0.610 & 0.698 & 0.690 \\
\hline & 6 & 0.632 & 0.608 & 0.594 & 0.608 & 0.635 & 0.702 & 0.692 \\
\hline & 7 & 0.620 & 0.610 & 0.602 & 0.603 & 0.615 & 0.666 & 0.659 \\
\hline & 8 & 0.615 & 0.610 & 0.609 & 0.620 & 0.641 & 0.655 & 0.650 \\
\hline
\end{tabular}

Note: Forecast horizon is given in quarters. Out-of-sample forecasts are generated 1985Q1-2007Q4. 


\section{Titles in Working Paper Series/Specialstudier}

Tidigare publicerade Working Paper finns på www.konj.se

\begin{tabular}{|c|c|c|c|}
\hline No & Author & Title & Year \\
\hline 101 & Östblom, Göran & $\begin{array}{l}\text { Nitrogen and Sulphur Outcomes of a Carbon Emis- } \\
\text { sions Target Excluding Traded Allowances - } \\
\text { An Input-Output Analysis of the Swedish Case }\end{array}$ & 2007 \\
\hline 102 & $\begin{array}{l}\text { Hammar, Henrik and } \\
\text { Åsa Löfgren }\end{array}$ & $\begin{array}{l}\text { Explaining adoption of end of pipe solutions and } \\
\text { clean technologies - Determinants of firms' invest- } \\
\text { ments for reducing emissions to air in four sextors in } \\
\text { Sweden }\end{array}$ & 2007 \\
\hline 103 & $\begin{array}{l}\text { Östblom, Göran and } \\
\text { Henrik Hammar }\end{array}$ & $\begin{array}{l}\text { Outcomes of a Swedish Kilometre Tax. An Analysis } \\
\text { of Economic Effects and Effects on NOx Emissions }\end{array}$ & 2007 \\
\hline 104 & $\begin{array}{l}\text { Forsfält, Tomas, } \\
\text { Johnny Nilsson and } \\
\text { Juhana Vartianinen }\end{array}$ & $\begin{array}{l}\text { Modellansatser i Konjunkturinstitutets medelfrist- } \\
\text { prognoser }\end{array}$ & 2008 \\
\hline 105 & Samakovlis, Eva & $\begin{array}{l}\text { How are Green National Accounts Produced in Prac- } \\
\text { tice? }\end{array}$ & 2008 \\
\hline 106 & $\begin{array}{l}\text { Markowski, Alek, } \\
\text { Kristian Nilsson and } \\
\text { Marcus Widén }\end{array}$ & $\begin{array}{l}\text { Strukturell utveckling av arbetskostnad och priser i } \\
\text { den svenska ekonomin }\end{array}$ & 2011 \\
\hline 107 & $\begin{array}{l}\text { Forslund, Johanna, } \\
\text { Per Johansson, Eva } \\
\text { Samakovlis and Maria } \\
\text { Vredin Johansson }\end{array}$ & $\begin{array}{l}\text { Can we by time? Evaluation. Evaluation of the } \\
\text { government's directed grant to remediation in Sweden }\end{array}$ & 2009 \\
\hline 108 & $\begin{array}{l}\text { Forslund, Johanna } \\
\text { Eva Samakovlis, Maria } \\
\text { Vredin Johansson and } \\
\text { Lars Barregård }\end{array}$ & $\begin{array}{l}\text { Does Remediation Save Lives? } \\
\text { On the Cost of Cleaning Up } \\
\text { Arsenic-Contaminated } \\
\text { Sites in Sweden }\end{array}$ & 2009 \\
\hline 109 & $\begin{array}{l}\text { Sjöström, Magnus and } \\
\text { Göran Östblom }\end{array}$ & $\begin{array}{l}\text { Future Waste Scenarios for Sweden on the Basis of a } \\
\text { CGE-model }\end{array}$ & 2009 \\
\hline 110 & Österholm, Pär & $\begin{array}{l}\text { The Effect on the Swedish Real Economy of the Fi- } \\
\text { nancial Crisis }\end{array}$ & 2009 \\
\hline 111 & Forsfält, Tomas & $\begin{array}{l}\text { KIMOD 2.0 Documentation of changes in the model } \\
\text { from January } 2007 \text { to January } 2009\end{array}$ & 2009 \\
\hline 112 & Österholm, Pär & $\begin{array}{l}\text { Improving Unemployment Rate Forecasts Using } \\
\text { Survey Data }\end{array}$ & 2009 \\
\hline 113 & Österholm, Pär & $\begin{array}{l}\text { Unemployment and Labour-Force } \\
\text { Participation in Sweden }\end{array}$ & 2009 \\
\hline 114 & $\begin{array}{l}\text { Jonsson, Thomas and } \\
\text { Pär Österholm }\end{array}$ & $\begin{array}{l}\text { The Properties of Survey-Based } \\
\text { Inflation Expectations in Sweden }\end{array}$ & 2009 \\
\hline 115 & $\begin{array}{l}\text { Hjelm, Göran and } \\
\text { Kristian Jönsson }\end{array}$ & $\begin{array}{l}\text { In Search of a Method for Measuring the Output Gap } \\
\text { of the Swedish Economy }\end{array}$ & 2010 \\
\hline 116 & Vartiainen, Juhana & Interpreting Wage Bargaining Norms & 2010 \\
\hline 117 & $\begin{array}{l}\text { Mossfeldt, Marcus and } \\
\text { Pär Österholm }\end{array}$ & $\begin{array}{l}\text { The Persistent Labour-Market Effects of the Financial } \\
\text { Crisis }\end{array}$ & 2010 \\
\hline 118 & $\begin{array}{l}\text { Östblom, Göran, Ma- } \\
\text { ria Ljunggren Söder- } \\
\text { man and Magnus Sjö- } \\
\text { ström }\end{array}$ & $\begin{array}{l}\text { Analysing future solid waste generation - Soft linking } \\
\text { a model of waste management with a CGE-model for } \\
\text { Sweden }\end{array}$ & 2010 \\
\hline
\end{tabular}




\begin{tabular}{|c|c|c|c|}
\hline 119 & $\begin{array}{l}\text { Broberg, Thomas, } \\
\text { Per-Olov Marklund, } \\
\text { Eva Samakovlisa and } \\
\text { Henrik Hammar }\end{array}$ & $\begin{array}{l}\text { Does environmental leadership pay off for Swed-ish } \\
\text { industry? - Analyzing the effects of environ-mental } \\
\text { investments on efficiency }\end{array}$ & 2010 \\
\hline 120 & $\begin{array}{l}\text { Gustavsson, Magnus } \\
\text { and Pär Österholm }\end{array}$ & $\begin{array}{l}\text { Labor-Force Participation Rates and the } \\
\text { Informational Value of Unemployment Rates: Evi- } \\
\text { dence from Disaggregated US Data }\end{array}$ & 2010 \\
\hline 121 & $\begin{array}{l}\text { Jonsson, Thomas and } \\
\text { Pär österholm }\end{array}$ & $\begin{array}{l}\text { The Forecasting Properties of Survey-Based Wage- } \\
\text { Growth Expectations }\end{array}$ & 2010 \\
\hline 122 & $\begin{array}{l}\text { Antipin, Jan-Erik, } \\
\text { Jimmy Boumediene } \\
\text { and Pär Österholm }\end{array}$ & $\begin{array}{l}\text { On the Usefulness of Constant Gain Least Squares } \\
\text { when Forecasting the Unemployment Rate }\end{array}$ & 2011 \\
\hline 123 & $\begin{array}{l}\text { Broberg, Thomas, } \\
\text { Tomas Forsfält and } \\
\text { Göran Östblom }\end{array}$ & $\begin{array}{l}\text { The Excess Cost of Supplementary Constraints in } \\
\text { Climate Policy: The Case of Sweden's Energy Inten- } \\
\text { sity Target }\end{array}$ & 2011 \\
\hline 124 & $\begin{array}{l}\text { Baard, Patrik, Henrik } \\
\text { Carlsen, Karin Ed- } \\
\text { vardsson Björnberg } \\
\text { and Maria Vredin } \\
\text { Johansson }\end{array}$ & $\begin{array}{l}\text { Scenarios and Sustainability. A Swedish Case Study of } \\
\text { Adaptation Tools for Local Decision-Makers }\end{array}$ & 2011 \\
\hline 125 & $\begin{array}{l}\text { Hansson, Sven Ove, } \\
\text { Karin Edvardsson } \\
\text { Björnberg and } \\
\text { Maria Vredin Johans- } \\
\text { son }\end{array}$ & $\begin{array}{l}\text { Making Climate Policy Efficient } \\
\text { Implementing a Model for Environmental Policy } \\
\text { Efficiency }\end{array}$ & 2011 \\
\hline 126 & $\begin{array}{l}\text { Antipin, Jan-Erik, } \\
\text { Farid Jimmy Boume- } \\
\text { diene and Pär Öster- } \\
\text { holm }\end{array}$ & $\begin{array}{l}\text { Forecasting Inflation Using Constant Gain Least } \\
\text { Squares }\end{array}$ & 2012 \\
\hline
\end{tabular}

